УДК $640.41(477)$

Полінкевич Оксана, доктор економічних наук, професор, Волинський національний університет імені Лесі Українки, кафедра підприсмництва і маркетингу, м. Луцьк, ORCID ID 0000-0001-6924-7296, e-mail: Kravomp@gmail.com

https://doi.org/10.29038/2411-4014-2020-04-24-29

\title{
СТРАТЕГІЇ РОЗВИТКУ ГОТЕЛЬНО-РЕСТОРАННОГО БІЗНЕСУ В УКРАЇНІ
}

У статті встановлено, що готельно-ресторанний бізнес у період Covid-19 зазнає значних збитків. Доведено, що в сучасних умовах потрібно розробляти стратегії розвитку, які будуть протидіяти внутрішнім та зовнішнім ризикам. Систематизовано основні стратегії розвитку готельно-ресторанного бізнесу в період Соvid19. Зокрема, виділено дві групи стратегій розвитку: стратегія утримання позитивного іміджу на ринку та стратегія подолання негативних наслідків пандемії Covid-19. Запропоновано створення смарт міст в межах готельно-ресторанних комплексів. Виділено 10 ознак, на підставі яких можна стверджувати про наявність розумних міст у межах готельно-ресторанного бізнесу. Стратегія розвитку готельно-ресторанного бізнесу повинна формуватися із урахуванням сучасних тенденцій розвитку. Для цього варто формувати підходи, які б зменшували рівень ризику, який спричинений появою негативних очікувань клієнтів. Для цього має бути використана маркетингова та збутова стратегія. Головну роль відіграватиме корпоративна культура, яка стане ядром майбутніх стратегічних змін. Важливою до впровадження є інноваційна стратегія, реалізація якої повинна відбуватися через створення розумних міст всередині готельно-ресторанного комплексу. Таки підхід мінімізує контакт із зовнішнім оточенням та сприятиме формуванню позитивного враження від якості послуг.

Ключові слова: стратегія, розвиток, готельно-ресторанний бізнес, розумне місто, ризики, Covid-19.

Полинкевич Оксана, доктор экономических наук, профессор, Волынский национальный университет имени Леси Украинки, кафедра предпринимательства и маркетинга, г. Луцк

\section{СТРАТЕГИИ РАЗВИТИЯ ГОСТИНИЧНО-РЕСТОРАННОГО БИЗНЕСА В УКРАИНЕ}

В статье установлено, что гостинично-ресторанный бизнес в период Covid-19 несет значительные убытки. Доказано, что в современных условиях нужно разрабатывать стратегии развития, которые будут противодействовать внутренним и внешним рискам. Систематизированы основные стратегии развития гостинично-ресторанного бизнеса в период Covid-19. В частности, выделены две группы стратегий развития: стратегия удержания положительного имиджа на рынке и стратегия преодоления негативных последствий пандемии Covid-19. Предложено создание смарт городов в пределах гостинично-ресторанных комплексов. Выделено 10 признаков, на основании которых можно утверждать о наличии разумных городов в пределах гостинично-ресторанного бизнеса. Стратегия развития гостинично-ресторанного бизнеса должна формироваться с учетом современных тенденций развития. Для этого следует формировать подходы, которые бы уменьшали уровень риска, который вызван появлением негативных ожиданий клиентов. Для этого должна быть использована маркетинговая и сбытовая стратегия. Главную роль будет играть корпоративная культура, которая станет ядром будущих стратегических изменений. Важной к внедрению является инновационная стратегия, реализация которой должна происходить через создание разумных городов внутри гостиничноресторанного комплекса. Таки подход минимизирует контакт с внешним окружением и будет способствовать формированию положительного впечатления от качества услуг.

Ключевые слова: стратегия, развитие, гостинично-ресторанный бизнес, умный город, риски, Covid-19.

Oksana Polinkevych, Professor, Doctor of Economics, Lesya Ukrainka Volyn National University, Department of Entrepreneurship and Marketing, 


\section{STRATEGIES OF DEVELOPMENT OF HOTEL AND RESTAURANT BUSINESS IN UKRAINE}

A promising area of the national economy of Ukraine is the development of hotel and restaurant business. All over the world, the hotel and restaurant business is developing quite rapidly. In 2017, the number of foreigners visiting Ukraine increased by about 1 million people - to 14.5 million. According to the World Travel \& Tourism Council, the number of jobs threatened by the Covid-19 pandemic could reach 75 million. In Europe, up to 10 million jobs in the field of travel and tourism are at risk, a loss of almost 552 billion dollars. In Ukraine, the losses are estimated at 0.5 million jobs. The article establishes that the hotel and restaurant business suffered significant losses during the Covid19 period. It is proved that in modern conditions it is necessary to develop development strategies that will counteract internal and external risks. The main strategies of hotel and restaurant business development in the period of Covid-19 are systematized. In particular, two groups of development strategies have been identified: the strategy of maintaining a positive image in the market and the strategy of overcoming the negative consequences of the Covid-19 pandemic. It is proposed to create smart cities within hotel and restaurant complexes. There are 10 signs on the basis of which it is possible to assert the existence of smart cities within the hotel and restaurant business. The strategy of development of hotel and restaurant business should be formed taking into account modern tendencies of development. To do this, it is necessary to develop approaches that would reduce the level of risk caused by the emergence of negative customer expectations. To do this, a marketing and sales strategy must be used. The main role will be played by corporate culture, which will be the core of future strategic changes. Important for implementation is the innovation strategy, the implementation of which should take place through the creation of smart cities within the hotel and restaurant complex. This approach minimizes contact with the external environment and promotes a positive impression of service quality.

Key words: strategy, development, hotel and restaurant business, smart city, risks, Covid-19.

Постановка проблеми. Перспективним напрямом національної економіки України є розвиток готельно-ресторанного бізнесу. У всьому світі готельний та ресторанний бізнес розвивається достатньо швидкими темпами. У 2017 році кількість іноземців, які відвідали Україну, зросла приблизно на 1 мільйон людей - до 14,5 мільйонів [3]. Проте статистика враховує також і малий прикордонний рух, що ускладнює точне визначення кількості туристів, які відвідали Україну. Найпопулярнішими напрямками були Київ, Львів й Одеса. У 2019 році кількість іноземних туристів зменшилася на 291031 осіб проти 2000 року [4]. Відповідно суттєве зменшення спричинене пандемією Covid-19, наявністю тимчасово окупованих територій, політичною нестабільністю на сході. Зважаючи на такий стан виникає необхідність розробки стратегій розвитку готельноресторанного бізнесу.

Аналіз останніх досліджень і публікацій. Спираючись на вище відзначене, варто констатувати i той факт, що стратегії розвитку готельно-ресторанного бізнесу знайшли своє відображення у різного роду дослідженнях. Зокрема, Ю. Земліна та О. Ліфіренко зазначили, що підвищення якості готельної пропозиції до рівня міжнародних стандартів, розширення ринків збуту і підготовка фахівців у відповідності 3 вимогами світових стандартів конче необхідне для забезпечення розвитку туристичної сфери в умовах поглиблення відносин між Україною i Європейським Союзом. Стратегія розвитку галузі потребує державної підтримки у фінансуванні за основними напрямами: залучення туристів на вибраних цільових ринках (рекламно-інформаційна діяльність, зокрема виставкова, створення мережі інформаційних центрів тощо); приведення національних нормативів, стандартів безпеки, якості товарів і послуг у відповідність до міжнародних вимог [2].

Остапенко Я. О., Параниця Н.А. зазначили, що туристичний бізнес в Україні стає доволі важливою сферою діяльності. Обсяги реалізації туристичного бізнесу зростають із кожним роком все більше, а це потребує розміщення туристів, що спонукає державне управління туризмом збільшувати спрямування своєї роботи на утворення конкурентоспроможного готельного господарства. Здійснили аналіз структури готельного бізнесу в Україні. Оцінили розвиток підприємств готельного господарства. Проаналізували теперішній стан готельної індустрії і розглянули його недоліки, визначили перспективи розвитку готельної галузі. Зазначили, що щоб об'єктивно оцінити підприємства готельного господарства, цих показників не досить, тому що розвиток готельного 
господарства відіграє важливу роль у сфері туристичних послуг [5].

У колективний монографії за редакцією Чепурди Г.М. визначено основні тенденції та проблеми розвитку готельно-ресторанної справи, проаналізували менеджмент та маркетинг готельно-ресторанного бізнесу [7].

Виділення невирішених раніше частин загальної проблеми. Проте у визначених працях не досліджувалися стратегії розвитку готельно-ресторанного бізнесу в умовах Covid-19.

Виклад основного матеріалу. Згідно 3 даними World Travel \& Tourism Council, кількість робочих місць, які опинились під загрозою внаслідок пандемії Covid-19, може сягнути 75 млн. В Європі під загрозою до 10 млн робочих місць у сфері подорожей та туризму, це втрати у розмірі майже 552 млрд доларів. В Україні втрати оцінюються у 0,5 млн робочих місць [1]. 3 метою оцінки впливу епідемії Covid-19 на сектор послуг тимчасового розміщення в Україні експерти Vertex Hotel Group та Colliers International (Україна) провели анкетування ринку готельної нерухомості України. Опитування проводилось 20-21 березня 2020 року, у ньому взяли участь 205 представників готельного бізнесу зі всіх регіонів України. Переважна більшість (96\%) опитаних констатувала різке зниження попиту, починаючи 313 березня 2020 року. Карантин та припинення міжнародного та внутрішнього пасажирського сполучення привели до суттєвого зниження заповнюваності готелів. Як наслідок $-85 \%$ всіх опитуваних респондентів або вже закрили свій заклад, або готуються до закриття чи думають над цим. «Серед опитуваних представників 5-ти зіркових готелів - 42\% зазначили, що не планують закривати заклад за жодних умов» [1].

Український бізнес був змушений реагувати і приймати необхідні антикризові заходи, з метою мінімізації збитків. Згідно з результатами опитування готельєрів, проведеного Colliers International спільно з Vertex Hotel Group в березні 2020 року, близько половини (47\%) опитаних представників п'ятизіркових готелів вдавалися до комплексних заходів з метою зменшення збитків [6]:

- переведення працівників у відпустку за свій рахунок,

- виведення з експлуатації номерного фонду,

- зменшення маркетингових бюджетів, інше.

Найчастіше для зниження витрат співробітників відправляли у відпустку. Майже $30 \%$ опитаних скоротили від 50 до 150 співробітників, 45\% відзначали, що скоротять до 10 робочих місць. Більше половини (61\%) представників готелів з номерним фондом до 50 номерів планували Скоротити до 10 робочих місць, ще $30 \%$ респондентів відзначали скорочення від 10 до 50 співробітників [6].

Отже, основні стратегії розвитку готельно-ресторанного бізнесу повинні бути направленими на подолання бізнес-ризиків, які виникають при пандемії. Загалом ризики можна згрупувати у три групи:

1) внутрішні ризики, до яких відносяться операційні, ризики грошово-фінансових втрат, маркетингові та збутові ризики, клієнтські ризики, ризик втрати здоров'я та безпеки працівників;

2) стратегічні ризики передбачають ризики неефективної бізнес-стратегії, невідповідності цілей та завдань;

3) зовнішні ризики, що містять конкурентні ризики, політико-правові, соціоекологічні, інформаційно-безпекові ризики.

Відповідно до цих груп ризиків можна виділити основні стратегії подолання ризиків, завдяки яким буде досягнутий розвиток готельно-ресторанного бізнесу та усунені диспропорції розвитку.

В умовах загострення пандемій та криз важливою стратегією розвитку для готельноресторанного бізнесу є використання інноваційних технологій не лише у виробничій діяльності, але й в управлінській та фінансовій. До основних інноваційних технологій в управлінській діяльності відносять впровадження систем управління готельно-ресторанним бізнесом, зокрема 3 використанням франшизи, формування нової корпоративної культури, яка грунтується на довірі, взаєморозумінні та клієнтоцентризмі. Крім того важливим елементом має стати замкнутість простору. Це можна досягти через створення смарт міст всередині готельно-ресторанних комплексів.

Важливим є погляд менеджерів на рівень задоволеності потреб клієнтів: іноземних і вітчизняних громадян, пасажирів різних видів транспорту, ділових людей, представників уряду й урядових делегацій, осіб, які перебувають у робочих відрядженнях, місцевого населення різних вікових груп і зайнятості в національному господарстві. 


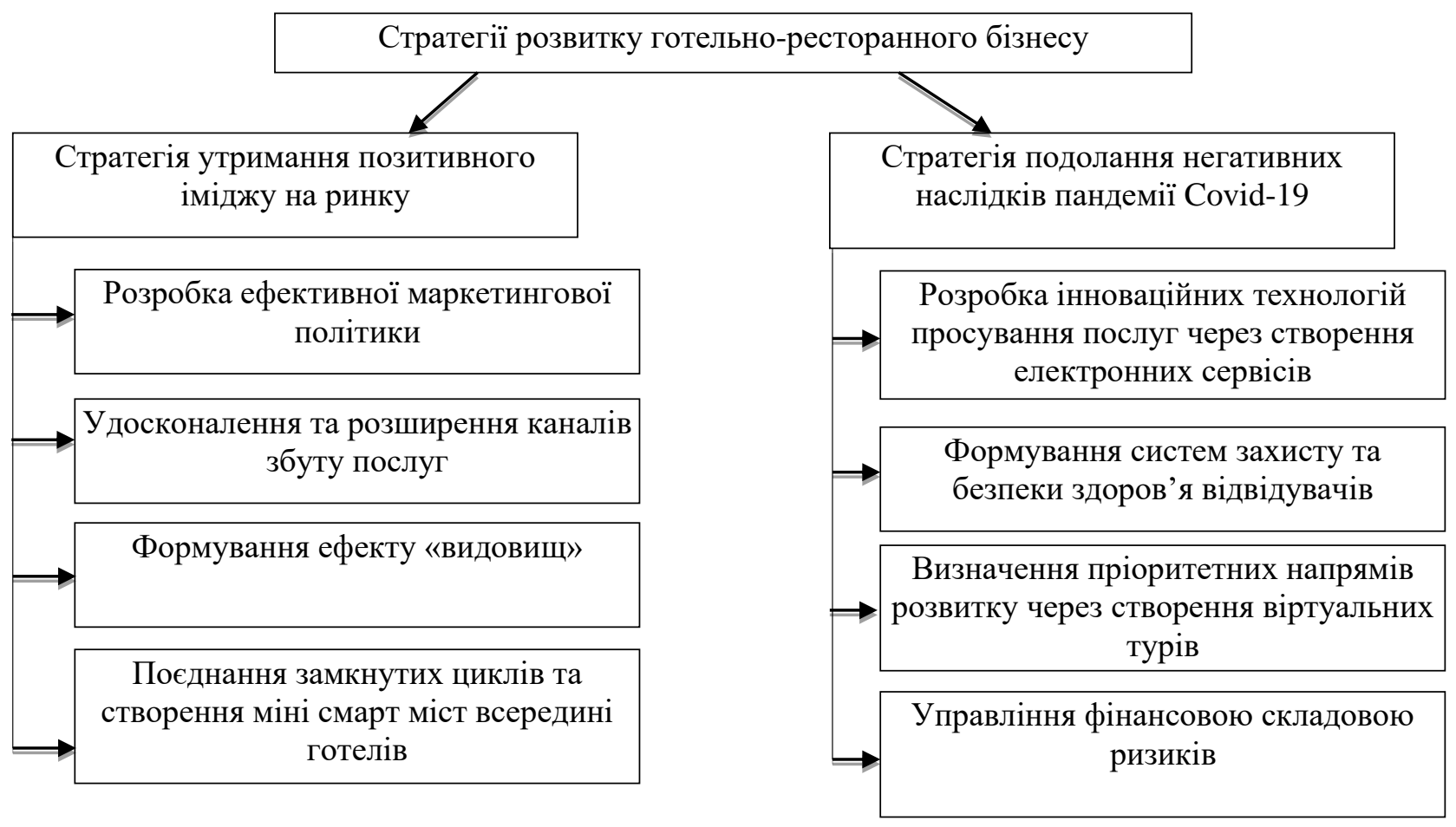

Рис. 1. Стратегія розвитку готельно-ресторанного бізнесу в умовах Covid-19

Такі обставини викликають потребу у поєднанні спеціальних знань із організації надання готельних і ресторанних послуг з метою підвищення ефективності підприємницької діяльності у сфері обслуговування. Відбувається посилення конкуренції серед готелів категорії 4-5-зірок у зв'язку із значним обсягом нової пропозиції, яка з'явилася на ринку за останній рік; зниження показників доходності готелів елітного сегменту на фоні збільшення пропозиції; підвищення зацікавленості інвесторів до сегменту низькобюджетних готелів.

Розумне місто всередині готельно-ресторанних комплексів - це концепція, в основі якої лежить місто, що використовує різноманітні інформаційні технології задля більш ефективного функціонування та відповідності потребам його жителів. Ідея такого міста полягає в тому, щоби завдяки збору інформації в режимі реального часу усі ресурси міста можна використовувати більш продуктивно. Це дозволяє економити кошти, раціональніше діяти та надавати сервіс вищого гатунку - тобто поліпшувати рівень життя споживачів послуг. Основною рушійною силою у побудові розумного міста $є$ збір та обробка великої кількості даних (Big Data). Саме управління даними дозволить менеджменту готельно-ресторанного комплексу підвищувати якість обслуговування відвідувачів. Ідея полягає у тому, щоб охоплювати такі сфери клієнтів, як: безпека, транспорт, медичні послуги, комунальне господарство, благоустрій тощо. Джерелами даних служать відеокамери, різні датчики, сенсори, інформаційні системи, які впроваджуються у повсякденне життя. Смарт міста в межах готельно-ресторанних комплексів повинні відповідати таким основним ознакам [9]:

1. Інтелектуальні системи управління процесом облслуговування. Вони передбачають підвищення безпеки та ефективності процесу, комфортності для клієнтів. Приміром, встановлення відеонагляду, подання інформації про сьогоднішні події та зміни на стан сенсорних дисплеїв мобільних пристроїв, інформування клієнтів про зміни тощо. Ця інформація дозволяє економити власний час та правильно розпоряджатися ним.

2. Розумний підхід до освітлення. Тут особливої популярності набувають датчики руху, які вмикають світло лише коли фіксують певні рухи чи присутність людини, і вимикають його, коли ви, приміром залишаєте приміщення. Крім того значним попитом користуються LED-лампи (Light Emitting Diode - світлотехнічні вироби для побутового, промислового та вуличного освітлення, у 
яких джерелом світла є світлодіоди), оскільки вони зменшують використання електроенергії до 80\% у порівнянні зі звичайними лампами накалювання, до яких ми звикли. Цікавим елементом стане освітлення скляних сходових кліток.

3. Залучення клієнтів смарт міста у межах готельно-ресторанного комплексу до управління управління ним через створення віртуальних платформ.

4. Розумний будинок. Ця технологія передбачає використання системи високотехнологічних пристроїв в номерах для найбільш комфортного перебування клієнтів. Зокрема виділяють кілька основних напрямків впровадження технологій розумного номеру: безпека (датчики руху, присутності, вібрації, розбиття скла, відкриття вікна або двері, відеоспостереження, електронні замки і модулі управління воротами, сирени), управління освітленням (розумні вимикачі, модулі управління шторами та ролетами, контролери для управління світлодіодними світильниками, датчики руху і присутності), управління кліматом (датчики вологості і температури, термостати для підтримки постійної температури або ii автоматичного регулювання, терморегулятори для управління потужністю батарей опалення, гігростати для підтримки постійної вологості або іiі регулювання).

5. Впровадження швидісної мережі Wi-Fi. На сьогодні у більшості європейських міст доступ до мережі Wi-Fi є нормою. Україна також прямує до цього і вже почала надавати бездротовий доступ до інтернету у громадському транспорті (метро, трамваї, тролейбуси), у центральних кварталах міст, публічних місцях тощо. А от у Барселоні вже важко знайти куточок, де Wi-Fi не працює.

6. Розумний транспорт всередині та за межами готельно-ресторанного комплексу. Він передбачає контроль за усім, що відбувається в салоні та зовні протягом руху і здатен передавати інформацію про порушення в органи влади.

7. Сповіщення про надзвичайні ситуації (HC). Персональна мережа оповіщення, що відправляє звичайні SMS-повідомлення на телефони абонентів, які знаходяться в зоні НС, надзвичайно ефективно працює у багатьох країнах. Таким чином вдається запобігти збільшенню кількості жертв, а також нападам паніки, яка у таких ситуаціях нерідко приносить не менше шкоди.

8. Кнопки екстреного реагування. Такі засоби допомагають правоохоронним органам швидше зреагувати на певні і події і прибути на місце оперативніше. Така практика має місце у США i показує позитивні результати.

9. Використання сонячних батарей. У багатьох містах світу, де це дозволяє клімат, така практика є невід'ємною складовою розумного міста. На дахах будівель встановлюються сонячні батареї, які можуть забезпечити автономне електропостачання для окремих квартир чи будинків загалом, в залежності від їх площі.

10. Безготівкові платежі. На сьогодні у розвинених країнах паперовими грошима майже не користуються - їм на заміну прийшли банківські платіжні картки. Але і це не є остаточним рішенням. У концепції розумного міста передбачається повсякчасне використання мобільних платежів, щоб жителям не доводилося носити з собою великі суми чи безліч карток, встановлюються спеціальні прилади, які можуть проводити оплати за допомогою мобільного телефону та спеціального за стосунку до нього.

Висновки та пропозиції. Таким чином, стратегія розвитку готельно-ресторанного бізнесу повинна формуватися із урахуванням сучасних тенденцій розвитку. Для цього варто формувати підходи, які б зменшували рівень ризику, який спричинений появою негативних очікувань клієнтів. Для цього має бути використана маркетингова та збутова стратегія. Головну роль відіграватиме корпоративна культура, яка стане ядром майбутніх стратегічних змін. Важливою до впровадження $є$ інноваційна стратегія, реалізація якої повинна відбуватися через створення розумних міст всередині готельно-ресторанного комплексу. Таки підхід мінімізує контакт із зовнішнім оточенням та сприятиме формуванню позитивного враження від якості послуг.

\section{Джерела та література}

1. Гришина О. Готелі на карантині: працюємо до останнього клієнта та впроваджуємо інновації. https://propertytimes.com.ua/gostinichnaya_nedvizhimost/goteli_na_karantini_pratsyuemo_do_ostannogo_klienta_ta_ vprovadzhuemo_innovatsiyi.

2. Земліна Ю., Ліфіренко О. Тенденції розвитку готельного бізнесу в Україні. Ресторанний і готельний 
консалтинг. Інновації. 2019. Т. 2. № $1 . \quad$ C. 121-131. URL: http://restauranthotel.knukim.edu.ua/article/viewFile/170430/171374.

3. Ільїн А. Україна гостинна: як розвивається готельний ринок. Hromadske. 2018. 8 квіт. URL: https://hromadske.ua/posts/iak-rozvyvaietsia-hotelnyi-rynok.

4. Кількість туристів, обслугованих туроператорами та турагентами, за видами туризму URL: http://www.ukrstat.gov.ua.

5. Остапенко Я. О., Параниця Н. В., Макаренко О. Я. Статистичний аналіз і тенденції розвитку готельного господарства в Україні. Приазовський економічний вісник. 2020. Вип. 1(18). C. 311-316. URL : http://pev.kpu.zp.ua/journals/2020/1_18_ukr/56.pdf.

6. Ринок готелів в Україні після карантину: ринок тільки починає відновлюватися. URL: https://100realty.ua/uk/articles/rinok-goteliv-v-ukraini-pisla-karantinu-rinok-tilki-pocinae-vidnovluvatisa.

7. Стан та перспективи розвитку туристичного та готельноресторанного бізнесу : колективна монографія / за ред. д.і.н., проф. Чепурди Г.М.; Черкас. держ. технол. ун-т. Черкаси : ЧДТУ, 2019. 157 с.

8. Стратегії та технології інноваційного розвитку корпорацій: монографія / за наук. ред. д-ра екон. наук, проф. О. М. Полінкевич. Луцьк : Вежа-Друк, 2018. 416 с.

9. 10 ознак розумного міста. URL: http://thefuture.news/smart-city

10. Polinkevych, O. and Kamiński, R. (2018). Corporate image in behavioral marketing of business entitie. Innovative Marketing, Vol. 14, Issue 1, 33-40. doi: 10.21511/im.14(1).2018.04

11. Polinkevych, O.M. (2016). Factors in the formation of advanced development of enterprises in the global crisis. Economic Journal - XXI, 156 (1-2), 59-63.

\section{References}

1. Hryshyna O. Hoteli na karantyni: pratsiuiemo do ostannoho kliienta ta vprovadzhuiemo innovatsii [Hotels in quarantine: we work to the last customer and implement innovations]. Retrieved from: https://propertytimes.com.ua/gostinichnaya_nedvizhimost/goteli_na_karantini_pratsyuemo_do_ostannogo_klienta_ta_ vprovadzhuemo_innovatsiyi [in Ukrainian].

2. Zemlina Yu., Lifirenko O. (2019). Tendentsii rozvytku hotelnoho biznesu v Ukraini [Trends in hotel business development in Ukraine]. Restorannyi i hotelnyi konsaltynh. Innovatsii - Restaurant and hotel consulting. Innovations, vol. 2, 1, 121-131. URL: http://restaurant-hotel.knukim.edu.ua/article/viewFile/170430/171374 [in Ukrainian].

3. Ilin A. Ukraina hostynna: yak rozvyvaietsia hotelnyi rynok [Hospitable Ukraine: how the hotel market is developing]. Hromadske. Hromadske. 2018. 8 квіт. Retrieved from: https://hromadske.ua/posts/iak-rozvyvaietsiahotelnyi-rynok [in Ukrainian].

4. Kilkist turystiv, obsluhovanykh turoperatoramy ta turahentamy, za vydamy turyzmu [Number of tourists served by tour operators and travel agents, by type of tourism]. Retrieved from: http://www.ukrstat.gov.ua [in Ukrainian].

5. Ostapenko Ya. O., Paranytsia N. V., Makarenko O. Ya. (2020). Statystychnyi analiz i tendentsii rozvytku hotelnoho hospodarstva v Ukraini [Statistical analysis and trends in the hotel industry in Ukraine]. Pryazovskyi ekonomichnyi visnyk - Priazovsky Economic Bulletin, 1(18), 311-316. Retrieved from : http://pev.kpu.zp.ua/journals/2020/1_18_ukr/56.pdf. [in Ukrainian].

6. Rynok hoteliv v Ukraini pislia karantynu: rynok tilky pochynaie vidnovliuvatysia [Hotel market in Ukraine after quarantine: the market is just beginning to recover]. Retrieved from: https://100realty.ua/uk/articles/rinok-gotelivv-ukraini-pisla-karantinu-rinok-tilki-pocinae-vidnovluvatisa [in Ukrainian].

7. Stan ta perspektyvy rozvytku turystychnoho ta hotelnorestorannoho biznesu [State and prospects of development of tourist and hotel restaurant business]: kolektyvna monohrafiia / za red. d.i.n., prof. Chepurdy H.M.; Cherkas. derzh. tekhnol. un-t. Cherkasy : ChDTU, 2019. 157 p. [in Ukrainian].

8. Stratehii ta tekhnolohii innovatsiinoho rozvytku korporatsii [Strategies and technologies of innovative development of corporations]: monohrafiia / za nauk. red. d-ra ekon. nauk, prof. O. M. Polinkevych. Lutsk : VezhaDruk, 2018. 416 p. [in Ukrainian].

9. 10 oznak rozumnoho mista [10 signs of a smart city].Retrieved from: http://thefuture.news/smart-city/ [in Ukrainian].

10. Polinkevych, O. and Kamiński, R. (2018). Corporate image in behavioral marketing of business entitie. Innovative Marketing, Vol. 14, Issue 1, 33-40. doi: 10.21511/im.14(1).2018.04 [in English].

11.Polinkevych, O.M. (2016). Factors in the formation of advanced development of enterprises in the global crisis. Economic Journal - XXI, 156 (1-2), 59-63. [in English]. 